\title{
PROFIL JENIS PERTANYAAN SISWA SMA BERDASARKAN TAKSONOMI BLOOM REVISI
}

\author{
Lissa \\ Universitas Wiralodra \\ e-mail: lissa@unwir.ac.id
}

\begin{abstract}
Abstrak
Penelitian ini bertujuan untuk mengetahui gambaran dari jenis pertanyaan siswa berdasarkan taksonomi Bloom revisi pada materi ekosistem di SMA Negeri 1 Sindang Indramayu. Subjek penelitian yaitu siswa kelas X MIA 4 SMA Negeri 1 Sindang Indramayu yang mengajukan pertanyaan pada saat materi ekosistem. Berdasarkan hasil analisis, jenis pertanyaan siswa pada materi ekosistem berdasarkan taksonomi Bloom revisi ranah kognitif yaitu C1 (mengingat) 25\%, C2 (memahami) 43,75\%, C3 (mengaplikasi) 12,5\%, C4 (mengalisis) 6,25\%, C5 (mengevaluasi) 12,5\% dan C6 (mencipta) 0\%. Sedangkan jenis pertanyaan siswa pada materi ekosistem berdasarkan taksonomi Bloom revisi dimensi pengetahuan yaitu level faktual $12,5 \%$, konseptual $37,5 \%$, prosedural $12,5 \%$, dan metakognitif $37,5 \%$. Hasil dari angket dan wawancara menunjukan bahwa siswa dalam mengajukan pertanyaan yaitu karena siswa merasa tertarik sehingga termotivasi dalam mencari tahu materi pelajaran yang sedang dipelajari. Selain itu siswa merasa masih kurang memahami materi dan konsep materi masih sulit untuk dipelajari. Sebagai acuannya jenis pertanyaan siswa ini yang dikategorikan berdasarkan taksonomi Bloom revisi ini dapat memudahkan guru dalam mengevaluasi siswa dalam belajar.
\end{abstract}

Kata kunci: Dimensi Pengetahuan; Jenis pertanyaan siswa; Taksonomi Bloom Revisi.

\begin{abstract}
The purpose of the research is to represent the classification of the students' questions based on revision of Bloom taxonomy about ecosystem material in SMAN 1 Sindang Indramayu. Subject of the research are the students of X MIA 4 SMA Negeri 1 Sindang Indramayu. Based on the result of analysis through Revision of Bloom Taxonomy, these questions classified into cognitive aspect of $\mathrm{C} 1$ (remembering) $25 \%$, C2 (Understanding) 43,75\%, C3 (Doing) 12,5\%, C4 (Analyzing) 6,25\%, C5 (Evaluating) 12,5\% and C6 (Creating) 0\%. While from knowledge aspect, factual was 12,5\%, conceptual $37,5 \%$, procedural $12,5 \%$, and cognitive $37,5 \%$. The result of questionnaire and interview shows that the students are motivated to ask questions because the material is exciting . Besides, the students find that it is difficult to understand the concept of material. By using revision of Bloom taxonomy, it will be easier for the teacher to classify or evaluate the students' questions or difficulties about the material.
\end{abstract}

Keywords: classification of students' question, knowledge dimension, revision of Bloom Taxonomy. 


\section{PENDAHULUAN}

Pendidikan hanya bisa didapatkan dengan belajar. Belajar adalah suatu proses usaha yang dilakukan seseorang untuk memperoleh suatu perubahan tingkah laku yang baru secara keseluruhan, sebagai hasil pengalamannya sendiri dalam interaksi dengan lingkungannya (Slameto, 2013:2). Untuk dapat terjadinya interaksi pada saat proses pembelajaran salah satu medianya adalah melalui pertanyaan.

Peran pertanyaan dalam pembelajaran Sains, dalam hal ini Biologi merupakan bagian penting untuk mengungkap rasa penasaran dari suatu fenomena ataupun pemantapan teori. Pertanyaan dapat diajukan oleh guru ataupun siswa, keduanya memiliki tujuan yang berbeda. Pertanyaan yang disuguhkan guru digunakan untuk menguji pemahaman materi, aplikasi teori di praktikum, serta mendeteksi motivasi belajar siswanya. Sedangakan apabila pertanyaan diajukan oleh siswa maka biasanya digunakan untuk mencari tahu penjelasan suatu konsep atau fenomena ilmiah, dan bahkan ada yang hanya digunakan untuk mencari perhatian (Widodo, 2006). Aktivitas bertanya bukan hanya sekedar melontarkan kalimat tanya akan tetapi didalamnya terdapat proses berpikir (Ennis, 2000).

Hasil observasi di lapangan, siswa dalam mengajukan jenis pertanyaan mengenai materi ekosistem sangat beragam. Hal ini terjadi karena tingkat pemahaman materi yang berbeda. Tentunya ini diakibatkan oleh beberapa hal misalnya siswa menyukai materi, kurangnya motivasi belajar siswa dan psikologi siswa dalam belajar turut memberi dampak siswa untuk mengajukan pertanyan tentang materi kepada guru. Salah satu pengelompokan jenis pertanyaan siswa adalah dengan menggunakan dasar taksonomi Bloom yang telah di revisi oleh Anderson dan Kartwohl (2015) yaitu mengingat (C1), memahami (C2), mengaplikasi (C3), menganlisis (C4), mengevaluasi (C5), dan mencipta (C6). Lebih dari itu, melalui taksonomi Bloom juga jenis pertanyaan dapat dibedakan ke dalam dimensi faktual, konseptual, prosedural, dan metakognitif.

Menggambarkan jenis pertanyaan siswa berdasarkan taksonomi Bloom revisi dapat digunakan untuk memetakan tingkat pemahaman siswa, dapat memilah siswa yang fokus belajar, mengetahui keterampilan berpikir siswa, dan mengetahui motivasi untuk belajar. Berdasarkan paparan tersebut, maka dilakukan penelitian dengan judul "Profil Jenis Pertanyaan Siswa SMA Berdasarkan Taksonomi Bloom Revisi”.

Tujuan penelitian ini adalah untuk melihat gambaran kualitas jenis pertanyaan siswa berdasarkan taksonomi Bloom revisi di SMAN I Sindang. Pertanyaan siswa diambil ketika proses pembelajaran berlangsung. Guru mengajar dengan pembelajaran yang biasa dilakukan tanpa adanya perlakuan khusus dan peneliti melakukan pengamatan terhadap beberapa jenis pertanyaan siswa. Jenis pertanyaan siswa kemudian digolongkan berdasarkan taksonomi Bloom revisi pada ranah kognitif dan dimensi pengetahuan. 


\section{METODE}

Penelitian ini dilaksanakan di SMA Negeri 1 Sindang Indramayu pada semester genap tahun pelajaran 2016/2017. Penelitian ini menggunakan jenis penelitian kualitatif. Subjek penelitian ini ditentukan dengan menggunakan purposive sampling. Menurut Sugiyono (2015:124) purposive sampling yaitu teknik pengambilan sampel sumber data dengan pertimbangan tertentu. Pertimbangan tertentu ini, berdasarkan kebutuhan peneliti sehingga akan memudahkan peneliti menjelajahi obyek atau situasi sosial yang diteliti. Purposive sampling ini lebih cocok digunakan untuk penelitian kualitatif. Adapun subjek yang akan diteliti pada penelitian ini adalah siswa kelas X MIA 4 di SMA Negeri 1 Sindang Indramayu dengan menggunakan lembar observasi, angket dan wawancara serta ditunjang dengan dokumentasi audio visual.

Teknik pengumpulan data yang digunakan dalam penelitian ini adalah observasi merupakan observasi yang didalamnya peneliti langsung turun ke lapangan untuk mengamati perilaku dan aktivitas individu-individu di lokasi penelitian (Creswell, 2013:267). Angket menurut Sugiyono (2015:199) merupakan teknik pengumpulan data yang dilakukan dengan cara memberi seperangkat pertanyaan atau pernyataan tertulis kepada responden untuk dijawabnya. Wawancara digunakan sebagai teknik pengumpulan data apabila peneliti ingin melakukan studi pendahuluan untuk menemukan permasalahan yang harus diteliti, dan juga apabila peneliti ingin mengetahui hal-hal dari responden yang lebih mendalam dan jumlah respondennya sedikit / kecil (Sugiyono, 2015:194). Dalam penelitian ini digunakan wawancara langsung dan mendalam kepada key informan dengan jenis tak berstruktur terkait dengan jenis pertanyaan siswa berdasarkan Taksonomi Bloom Revisi.

Teknik analisis data pada penelitian ini yaitu menggunakan data reduction, data display dan conclusion drawing/verivication. Pengujian keabsahan data menggunakan uji kreadibilitas, uji transferability, uji dependability, dan uji konfirmability.

\section{HASIL DAN PEMBAHASAN}

Hasil analisis jenis pertanyaan siswa berdasarkan taksonomi Bloom revisi pada materi ekosistem di SMA Negeri 1 Sindang Indramayu yaitu pada pertanyaan ranah kognitif yaitu pada Tabel 1 . 
Tabel 1. Hasil Analisis Jenis Pertanyaan Siswa Pada Ranah Kognitif

\begin{tabular}{llcc}
\hline No & Pertanyaan Siswa & $\begin{array}{c}\text { Jumlah Siswa } \\
\text { Bertanya }\end{array}$ & $\begin{array}{c}\text { Prosentase } \\
\text { (\%) }\end{array}$ \\
\hline 1. & C1 (Mengingat) & 4 & $25 \%$ \\
2. & C2 (Memahami) & 7 & $43,75 \%$ \\
3. & C3 (Mengaplikasi) & 2 & $12,5 \%$ \\
4. & C4 (Menganalisis) & 1 & $6,25 \%$ \\
5. & C5 (Mengevaluasi) & 2 & $12.5 \%$ \\
6. & C6 (Mencipta) & 0 & $0 \%$ \\
\hline
\end{tabular}

Hasil dari Tabel 1 tersebut didapatkan bahwa jumlah pertanyaan ranah kognitif tingkat C1 (mengingat) terdapat 4 orang siswa yang bertanya (25\%), tingkat C2 (memahami) terdapat 7 orang siswa yang bertanya (43,75\%), C3 (mengaplikasi) terdapat 2 orang siswa bertanya (12,5\%), C4 (menganalisis) terdapat 1 orang siswa bertanya (6,25\%), C5 (mengevaluasi) terdapat 2 orang siswa bertanya (12,5\%), dan C6 (mencipta) tidak ditemukan siswa yang bertanya $(0 \%)$.

Beberapa pertanyaan tersebut dapat mengetahui nilai prosentase (\%) siswa yang bertanya pada tingkatan C1 (mengingat), C2 (memahami), C3 (mengaplikasi), C4 (menganalisis), C5 (mengevaluasi), dan C6 (mencipta) pada ranah kognitif berdasarkan taksonomi Bloom Revisi menurut Anderson and Krathwohl (2015). Sedangkan hasil analisis pada jenis pertanyaan dimensi pengetahuan yaitu terdapat dalam Tabel 2.

\begin{tabular}{|c|c|c|c|}
\hline No & $\begin{array}{c}\text { Pertanyaan Siswa pada } \\
\text { Ranah Kognitif }\end{array}$ & $\begin{array}{c}\text { Jumlah Siswa } \\
\text { Bertanya }\end{array}$ & Prosentase (\%) \\
\hline 1 & Faktual & 2 & $12,5 \%$ \\
\hline 2 & Konseptual & 6 & $37,5 \%$ \\
\hline 3 & Prosedural & 2 & $12,5 \%$ \\
\hline 4 & Metakognitif & 6 & $37,5 \%$ \\
\hline
\end{tabular}

Tabel 2 menunjukkan nilai prosentase (\%) tersebut didapatkan dari perhitungan yang didapatkan dari jumlah jenis pertanyaan siswa pada materi ekosistem. Pengkategorian tersebut untuk memahami dan mengetahui kualitas pertanyaan siswa pada dimensi pengetahuan taksonomi Bloom revisi. Berdasarkan tabel dapat diketahui bahwa pertanyaan pada dimensi pengetahuan level faktual yaitu diajukan oleh sebanyak 2 orang siswa atau dengan nilai prosentase $12,5 \%$ dari total siswa yang bertanya. Pertanyaan level konseptual yaitu dengan jumlah 6 orang siswa atau sama dengan nilai prosentase $37,5 \%$ dari total siswa yang bertanya. Pertanyaan level prosedural yaitu dengan jumlah 2 orang siswa atau sama dengan 12,5\% dari total siswa yang bertanya. 
Pertanyaan metakognitif yaitu dengan jumlah 6 orang siswa atau sama dengan nilai prosentase $37,5 \%$ dari total siswa yang bertanya pada materi ekosistem.

Gezer (2013) menyatakan bahwa tingkat kesukaran berdasarkan urutan dari ranah kognitif dan dimensi pengetahuan yaitu bahwa dalam ranah kognitif komposisi yang sesuai yaitu yang dikategorikan mudah, sedang dan sukar. Katergori sukar yaitu dimulai dari dari C1-C2 dengan komposisi dalam prosentase $25 \%$. Kategori sedang yaitu dimulai dari C3C4 dengan komposisi 50\%. Kategori sukar yaitu dimulai dari tahap C5-C6 dimana prosentasenya yaitu sekitar $25 \%$.

Hasil dari penelitian ini didapatkan bahwa siswa kelas X MIA 4 SMA Negeri 1 Sindang masih dalam tingkat kognitif cukup. Hal ini terlihat dari hasil penelitian bahwa didapatkan data berupa prosentase pertanyaan siswa masih terkait dengan level C1-C2 dengan kisaran paling tinggi terdapat pada pertanyaan C2 yaitu 43,75\% dari total jumlah siswa bertanya. Akan tetapi apabila ditunjang dari segi prestasi sekolah seharusnya siswa SMA Negeri 1 Sindang bukan terdapat pada tahap kognitif yang rendah. Hal ini bisa saja terjadi dikarenakan siswa belum optimal dalam belajar walaupum secara aktif guru memotivasi siswa dalam belajar.

Komposisi pada tahap sedang yaitu dimulai dari tahap C3-C4 didapatkan data sesuai hasil penelitian yaitu sebesar C3 12,5\% dan C4 sebesar 6,25\%. Hal ini dianggap bahwa siswa ranah kognitifnya lumayan. Hal ini ditunjang dengan data kesesuaian gaya kognitif siswa dalam belajar. Data yang didapatkan yaitu pada tahap sedang ini bahwa level C3 lebih dominan dari level C4. Level C4 ini merupakan data paling rendah dari pertanyaan siswa yang diajukan kepada guru. Mungkin saja hal ini terjadi karena gaya kognitif siswa terdapat pengaruh seperti moptivasi belajar yang rendah dan sistem pembelajaran yang aktif masih cenderung hanya pada tahap mengingat dan memahami belum terkonsep untuk memacu siswa dalam tahap analisis dan aplikasi.

Komposisi sukar dari C5-C6 hanya didapatkan data C5 saja yang ditemukan. C5 ini sebesar $12,5 \%$ hal ini setara dengan siswa yang bertanya pada tahap $\mathrm{C} 3$. Hal ini mungkin saja dikarenakan siswa mulai terbiasa dengan pembelajaran yang aktif sehingga siswa timbul rasa keberanian dan motivasi dalam belajar sehingga mengikuti pembelajaran dengan baik. Sedangkan tahap C6 tidaklah ditemukan dikarenakan tahap C6 untuk kategori anak SMA masih kurang cocok dikarenakan pemikiran siswa pada jenjang ini belum mengarah ke level mencipta.

Pertanyaan-pertanyaan yang diajukan oleh siswa tersebut dapat mengetahui gambaran karakteristik siswa dalam belajar dan bertanya. Karakter siswa dalam penelitian ini dilihat dari berbagai aspek diantaranya yaitu keaktifannya dalam belajar, motivasi dalam belajar, ranah kognitif siswa dan dimensi pengetahuan siswa dalam mengajukan pertanyaan pada saat proses pembelajaran berlangsung yang penulis lihat dari instrumen 
penelitian yaitu observasi, angket dan wawancara. Adapun keaktifan siswa dalam belajar dilihat dari seberapa antusiasnya siswa mengikuti pembelajaran. Terkait motivasi siswa dalam belajar juga dapat melihat karakter siswa dalam belajar. Sehingga siswa mempunyai keberanian untuk mengungkapkan tidak pahamnya sebuah materi yang diungkapkan melalui pertanyaan. Ranah kognitif dan dimensi pengetahuan tidak dapat dipisahkan dari karakter siswa dalam belajar sehingga memunculkan jenis pertanyaan yang sangat beragam dan bervariasi. Karakteristik kognitif siswa menurut Slameto (2013:102) yaitu persepsi, perhatian, mendengarkan, ingatan, readiness (kesiapan) dan transfer, inteligensi, kreativitas, dan gaya kognitif.

Jumlah siswa dalam kelas X MIA 4 SMA Negeri 1 Sindang yang bertanya pada materi ekosistem yaitu sebanyak 16 siswa dengan pertanyaan yang sangat beragam. Siswa dalam mengajukan pertanyaan sesuai dengan keinginannya untuk bertanya dan sesuai dengan kondisi psikologis siswa tersebut dalam mengikuti pembelajaran ekosistem. Karakter siswa tersebut bisa menjadikan kualitas beberapa pertanyaan yang diajukan kepada guru pada materi pembelajaran tertentu.

Hasil dari kegiatan penelitian ini menghasilkan beberapa pertanyaan siswa pada materi ekosistem yang menarik untuk dikaji. Adapun siswa yang mengajukan pertanyaan yaitu siswa yang memiliki tingkat motivasi dan keaktifan yang tinggi di dorong dengan rasa ingin tahu tentang materi ekosistem yang tinggi pula. Pembelajaran ekosistem dianggap menarik sehingga siswa merasa senang untuk mempelajarinya. Hal lainnya yaitu ketika guru mendorong siswa untuk mengajukan pertanyaan banyak siswa yang berantusias untuk bertanya kepada guru. Penggunaan metode pembelajaran yang bisa memfokuskan siswa dalam belajar sehingga belajar terjadi secara multi arah antara guru dan siswa atau sebaliknya antara siswa dan guru. Sehingga siswa banyak yang mengajukan pertanyaan terkait materi ekosistem.

Beberapa pertanyaan siswa tersebut kemudian dianalisis berdasarkan taksonomi Bloom revisi pada ranah kognitif dan dimensi pengetahuan. Taksonomi Bloom revisi ini dikembangkan oleh Anderson and Krathwohl (2001) dengan melibatkan dua dimensi yaitu dengan enam proses kognitif dan empat jenis pengetahuan (Kuswana, 2014:109). Hal ini sejalan dengan penelitian yang pernah dilakukan oleh Fathiyanihayati, Asri. Dkk. (2013); Rahmawati (2013); dan Rahmi (2016) yang mengkaji ragam pertanyaan siswa berdasarkan taksonomi Bloom revisi menurut Anderson and Krarthwohl.

Jenis pertanyaan yang diajukan oleh siswa tersebut kemudian akan dikelompokan ke dalam ranah kognitif dan dimensi pengetahuan pada taksonomi Bloom revisi. Pertanyaan ranah kognitif ini dikategorikan pada tingkat C1 (mengingat), C2 (memahami), C3 (mengaplikasi), C4 (menganalisis), C5 (mengevaluasi), dan C6 (mencipta). Pertanyaan 
ranah kognitif yang dilihat dari ragam jenis pertanyaan siswa ini diambil pada saat pembelajaran materi ekosistem di kelas.

Proses penelitian ini berlangsung secara aktif, karena semuanya berlangsung secara optimal baik itu antar siswa maupun guru dan siswa. Metode pembelajaran tanya jawab juga bisa mendorong siswa untuk berperan aktif dalam belajar. Hal ini berarti menyatakan bahwa metode tanya jawab masih bisa memotivasi siswa dalam belajar secara optimal. Metode ini mengajak siswa untuk mempunyai rasa tanggung jawab dan keberanian, karena siswa memacu untuk terlihat aktif dan berani dalam mengungkapkan ketidak pahamannya pada materi yang sedang dipelajari.

Biasanya siswa dalam bertanya apabila memang guru memberikan kesempatan siswa untuk mengajukan pertanyaan. Akan tetapi siswa akan cenderung bertanya sesuai dengan pemahamannya terhadap materi yang sedang dipelajari. Beberapa karakter siswa tersebut dapat terpengaruhi oleh semakin meningkatnya pemikiran siswa maka ranah kognitif dan dimensi pengetahuan pada taksonomi Bloom revisi dapat mempengaruhi tingkat karakter siswa dalam belajar. Misalnya yaitu karakter siswa yang semakin berkembang mengikuti pola pemikirannya sehingga semakin baik pula pertanyaan yang diajukan oleh siswa tersebut. Karakter siswa tersebut tergantung dari tingkat pemahaman dan gaya berfikir siswa dalam belajar.

Dasar dari pengkategorian pertanyaan-pertanyaan siswa tersebut dilihat dari taksonomi Bloom revisi menurut Anderson and Krathwohl (2015). Sedangkan komposisi dari tingkat mudah, sedang dan tinggi dilihat dari komposisi bahwa tingkat C1-C2 dikelompokan mudah, C3-C4 dikelompokan sedang dan C5-C6 dikelompokan tinggi. Dalam kajian ini taksonomi Bloom revisi sendiri digunakan untuk mengkategorikan pertanyaan siswa yang dikelompokan ke dalam ranah kognitif dan dimensi pengetahuan. Diharapkan dari hasil penelitian ini yaitu untuk memudahkan dalam peningkatan tujuan pembelajaraan yang akan dicapai oleh guru dan siswa.

\section{SIMPULAN}

Jenis pertanyaan siswa yang diajukan pada materi ekosistem oleh siswa kelas $\mathrm{X}$ MIA 4 SMA Negeri 1 Sindang dapat diketahui hasilnya yaitu pada komposisi mudah yaitu $25 \%$, sedang $50 \%$, dan sukar $25 \%$. Akan tetapi fakta dilapangan didapatkan data bahwa pertanyaan siswa masih dominan pada komposisi sedang. Hasil analisis deskriptif kualitatif menunjukan bahwa nilai prosentase (\%) jenis pertanyaan siswa berdasarkan taksonomi Bloom revisi pada ranah kognitif yaitu pada tingkat $\mathrm{C} 1$ (mengingat) $0 \%, \mathrm{C} 2$ (memahami) 35\%, C3 (mengaplikasi) 5\%, C4 (menganalisis) 45\%, C5 (mengevaluasi) 15\%, dan C6 (mencipta) $0 \%$. Sedangkan pada dimensi pengetahuan pada level faktual yaitu $25 \%$, konseptual $45 \%$, prosedural $5 \%$, dan metakognitif $25 \%$. 


\section{DAFTAR PUSTAKA}

Anderson, Lorin W., Krathwohl R. 2015. Kerangka Landasan Untuk Pembelajaran, Pengajaran, dan asesmen (Revisi Taksonomi Pendidikan Bloom), terj. Agung Prihantoro. Yogyakarta: Pustaka Pelajar.

Creswell, John W. 2013. Research Design Pendekatan Kualitatif, Kuantitatif, dan Mixed. Terj. Achmad Fawaid. Yogyakarta: Pustaka Pelajar.

Ennis, R. H. 2011. An Outline of Goals for a Critical Thinking Curriculum and Its Assessment. 2002.

Fathiyanihayati, A., Hidayati, S., Yuliati. 2013. Ragam Pertanyaan Siswa MAN Yogyakarta III Kelas X Dalam Pembelajaran Biologi Berdasarkan Perbedaan Pokok Bahasan, Jurnal Pendidikan Biologi, (5): 7.

Gezer, M., ONER SUNKUR, M., \& Sahin, I. F. 2014. An Evaluation Of The Exam Questions Of Social Studies Course According To Revized Bloom's Taxonomy. Education Sciences \& Psychology, 28(2).

Kuswana, Wowo Sunaryo. 2014. Taksonomi Kognitif Perkembangan Ragam Berpikir. Bandung: Rosda.

Rahmawati, I. D. 2013.Peningkatan Kemampuan Bertanya Siswa Pada Mata Pelajaran IPA Melalui Penerapan Strategi Pembelajaran The Learning Cell Pada Siswa Kelas IV SDN Pengkok 1 Kedawung Sragen Tahun Ajaran 2012/2013. Skripsi. Universitas Muhamadiyah Surakarta. Surakarta: Tidak Diterbitkan [Online].

Rahmi, Q. 2016. Analisis Keterampilan Bertanya Siswa pada Konsep Gerak dengan Strategi Pembelajaran Question Student Have. Skripsi. Universitas Islam Negeri Jakarta. Jakarta: Tidak Diterbitkan [Online].

Slameto. 2013. Belajar dan Faktor-Faktor yang Mempengaruhi. Jakarta: Rineka Cipta.

Sugiyono. 2015. Metode Penelitian Pendidikan Pendekatan Kuantitatif, Kualitatif, dan $R N D$. Bandung: Alfabeta.

Widodo, A., \& Pujiastuti, S. 2006. Profil Pertanyaan Guru dan Siswa dalam Pembelajaran Sains. Jurnal Pendidikan dan Pembelajaran, 4(2), 139-148. 